\title{
1 Lead contamination of the Seine River, France: geochemical 2 implications of a historical perspective.
}

3 Sophie Ayrault ${ }^{\mathrm{a},}$, Matthieu Roy-Barman ${ }^{\text {a }}$, Marie-Françoise Le Cloarec ${ }^{\text {a }}$, Cindy

4 Rianti Priadi $^{\text {a }}$, Philippe Bonté ${ }^{\text {a }}$, Christa Göpel ${ }^{\text {b }}$

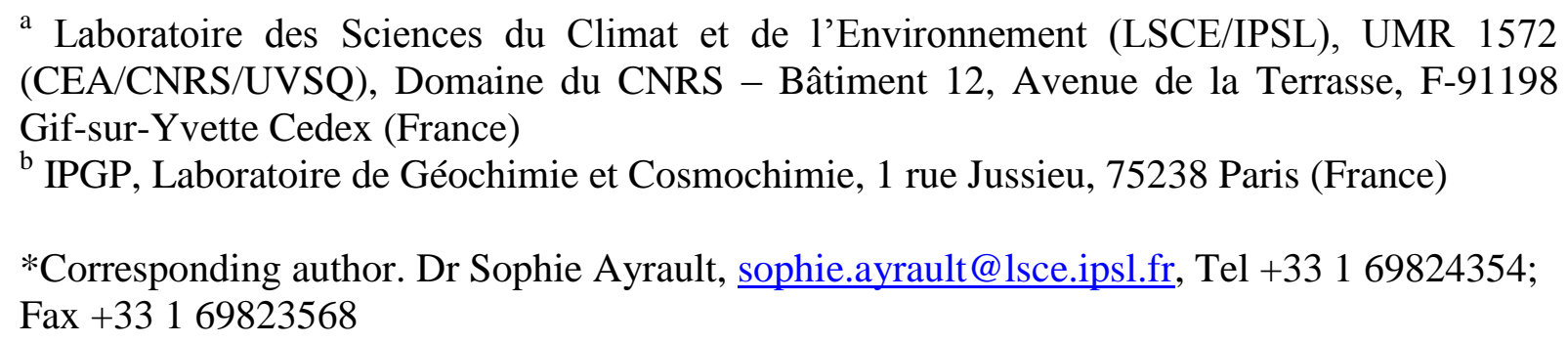
(CEA/CNRS/UVSQ), Domaine du CNRS - Bâtiment 12, Avenue de la Terrasse, F-91198 Gif-sur-Yvette Cedex (France)

${ }^{\mathrm{b}}$ IPGP, Laboratoire de Géochimie et Cosmochimie, 1 rue Jussieu, 75238 Paris (France)

*Corresponding author. Dr Sophie Ayrault, sophie.ayrault@1sce.ipsl.fr, Tel +33 1 69824354; Fax +33169823568

\section{Abstract}

Four sediment cores collected in the Seine River basin and dated between 1916 and 2003 were analysed for lead concentrations and isotopic composition. In all four cores, the measured $\mathrm{Pb}$ concentration (up to $460 \mathrm{mg} \cdot \mathrm{kg}^{-1}$ ) lies significantly above the natural background (27-40 mg. $\mathrm{kg}^{-1}$ ), although a significant decrease (down to $75 \mathrm{mg} \cdot \mathrm{kg}^{-1}$ ) was observed during the second half of the $20^{\text {th }}$ century which can be explained by the reduction of lead emissions. The ${ }^{206} \mathrm{~Pb} /{ }^{207} \mathrm{~Pb}$ ratio measured in these samples indicates that the main source of $\mathrm{Pb}$ used in the Paris conurbation is characterized by a "Rio Tinto" signature (defined as $\left.{ }^{206} \mathrm{~Pb} /{ }^{207} \mathrm{~Pb}=1.1634 \pm 0.0001\right)$. A high contribution, up to $25 \%$, from the leaded gasoline (characterized by ${ }^{206} \mathrm{~Pb} /{ }^{207} \mathrm{~Pb}=1.08 \pm 0.02$ ) is revealed in the Seine River downstream Paris, indicating that lead from the leaded gasoline is preferentially released to the river.

The dominating $\mathrm{Pb}$ signature in the Paris conurbation that is currently sampled through incinerators fumes $\left({ }^{206} \mathrm{~Pb} /{ }^{207} \mathrm{~Pb}=1.1550 \pm 0.0005\right)$ and waste water treatment plant $\left({ }^{206} \mathrm{~Pb} /{ }^{207} \mathrm{~Pb}=1.154 \pm 0.002\right)$, represents a mixture of highly recycled lead from the Rio Tinto mine and lead from leaded gasoline (imprinted by the low ${ }^{206} \mathrm{~Pb} /{ }^{207} \mathrm{~Pb}$ of the Broken Hill mine). This signature is called "urban" rather than "industrial", because it is clearly distinct from the $\mathrm{Pb}$ that is found in areas contaminated by heavy industry, i.e. the heavy industries located on the Oise River which used lead from European ores characterized by high ${ }^{206} \mathrm{~Pb} /{ }^{207} \mathrm{~Pb}$ ratios ( 1.18-1.19) and possibly a minor amount of North American lead $\left({ }^{206} \mathrm{~Pb} /{ }^{207} \mathrm{~Pb}\right.$ ratios $\left.>1.20\right)$. The "urban" signature is also found in a rural area upstream of Paris in the 1970's. At the Seine River mouth in 2003, Pb with an urban signature represents $70 \%$ of the total $\mathrm{Pb}$ sediment content, with the $30 \%$ remaining corresponding to natural $\mathrm{Pb}$. 
Keywords: Lead, isotope, pollution, Seine, industrial lead, urban lead, Paris, Broken Hill, Rio

Tinto, gasoline.

39

40

41

\section{Introduction.}

The Seine river basin $\left(67,500 \mathrm{~km}^{2}\right)$ drains one of the most urbanised areas in Europe. It covers $14 \%$ of the French territory but accounts for $25 \%$ of the agriculture production, 25 to $30 \%$ of the industrial activity and $23 \%$ of the French population. In the Paris conurbation $\left(2,740 \mathrm{~km}^{2}, 9.5\right.$ million inhabitants), the Seine water and sediments are heavily contaminated by metals. Unfortunately, the sources and pathways of these contaminations are not well understood (Thévenot et al., 2007; Meybeck et al. 2007; Le Cloarec et al., 2009).

Lead $(\mathrm{Pb})$ represents one of the major metallic contaminants of the Seine River. Dredged sediments are characterized by such high $\mathrm{Pb}$ contents that they are classified in the "moderated to highly contaminated sediment" category (Meybeck et al., 2007). Although the release of $\mathrm{Pb}$ into the environment has been strongly reduced, the lead contamination of the sediments on the downstream part of the Seine River is still three times higher than the geochemical background which is in the range of $27-40 \mathrm{mg} \mathrm{kg}^{-1}$ (Thévenot et al., 2007).

The $\mathrm{Pb}$ concentration measured in the river sediments clearly reveals the high level of contamination of the river. However, it does not provide any information on the different sources of this contamination. The $\mathrm{Pb}$ isotopic composition represents a powerful tool to evaluate the different sources of $\mathrm{Pb}$ (natural, industrial, leaded gasoline) that are released into the environment (Monna et al., 2000; Shotyk et al., 1998). The overall balance of the lead cycle in the environment is not straightforward because some $\mathrm{Pb}$ stocks are strongly recycled and hence produce very small environmental leaks (e.g., $\mathrm{Pb}$ for car accumulators), whereas others are directly released into the environment (emission of tetraethyl $\mathrm{Pb}$ from leaded gasoline).

Gasoline lead additives were the main source of $\mathrm{Pb}$ to the road dust $\left({ }^{206} \mathrm{~Pb} /{ }^{207} \mathrm{~Pb}=\right.$ $1.101 \pm 0.001$ ), but were less important for indoor dust accumulated from 1971 to 1981 $\left({ }^{206} \mathrm{~Pb} /{ }^{207} \mathrm{~Pb}=1.120 \pm 0.001\right)$ and even lower for the Seine River sediment $\left({ }^{206} \mathrm{~Pb} /{ }^{207} \mathrm{~Pb}=\right.$ $1.152 \pm 0.002$ ) sampled in 1979 (Elbaz-Poulichet et al., 1986). The contribution of gasoline lead additives to the Seine River decreased from 1979 to $2000\left({ }^{206} \mathrm{~Pb} /{ }^{207} \mathrm{~Pb}=1.169\right.$; Millot et al., 2004). In 1997, the lead contained in the street dust of Paris $\left({ }^{206} \mathrm{~Pb} /{ }^{207} \mathrm{~Pb}=1.151\right)$ came 
mostly from gasoline lead additives, except nearby the Eiffel Tower $\left({ }^{206} \mathrm{~Pb} /{ }^{207} \mathrm{~Pb}=1.174\right)$ where dust was contaminated by the lead contained in the paint used on the tower (Nageotte and Day, 1998). There are also differences in isotopic compositions of aerosols sampled in different sites in Paris, in 1989 and 1995 (Véron et al., 1999). From 1995 to 2002, the main lead source to Parisian aerosols shifted from gasoline to the so-called "industrial" endmember (Widory et al., 2004). As a whole, the previous data underline the spatial and temporal variability of the lead sources and their respective contribution to the pollution of the Paris conurbation, claiming for an integrative study.

Moreover, in order to evaluate the efficiency of past and ongoing environmental policies whose major goal is to reduce the heavy metal contamination, it is important to establish a historical record of the Seine River contamination and to detect its different contamination sources.

Sediment cores represent valuable archives of the anthropogenic river contamination (Alfonso et al., 2001; Chillrud et al., 2003; Arnaud et al., 2004; Soster et al., 2007; Le Cloarec et al., 2009), provided that they are sampled in undisturbed sites with continuous sedimentation. Unfortunately, navigation and channel dredging prevent continuous accumulation of sediments in the Seine River bed. The Seine River has no delta where marsh cores (Alfonso et al., 2001) can be sampled. Floodplains offer an alternative, but undisturbed floodplains are extremely rare along the Seine River. It was very difficult to find deposit sites allowing temporal reconstructions over the last 100 years (Le Cloarec et al., in press).

Here, we report the $\mathrm{Pb}$ concentration and isotopic signature in four cores covering different periods determined with the ${ }^{137} \mathrm{Cs}$ - and ${ }^{210} \mathrm{~Pb}$ method, and three sites. This allows to:

1) Assess whether the changes in $\mathrm{Pb}$ contamination in the Seine River are related to changes of the $\mathrm{Pb}$ source(s).

2) Constrain the actual $\mathrm{Pb}$ source(s) of the Seine River.

3) Evaluate the impact of leaded gasoline emissions on the past and present Seine River contamination.

\section{Materials and methods.}

\subsection{Sampling sites and sediment core dating}

\section{Figure 1}


The core TR01 was collected in an upstream Seine River site (Fig.1). This sampling site is located on an oxbow lake of the "Canal de la Haute Seine" that was built between 1806 and 1851 in order to connect Paris with agricultural and coal mining areas. This site drains an area of $3577 \mathrm{~km}^{2}$, and the population density is low, 40 inhabitants $\mathrm{km}^{-2}$. Agriculture and forestry are the major activities. The 80-cm long TR01 core was collected during March 2002. Bed soft sediments were cored using a hand pushed $10-\mathrm{cm}$ diameter plastic tube, at a depth of 1 meter below the water surface.

Two cores, B2 and M1, were collected in the Seine River floodplain, about $100 \mathrm{~km}$ downstream of Paris and its main waste water treatment plant (WWTP Seine Aval at Achères, see Fig. 1). These two sampling sites drain $96 \%$ of the Seine River basin and are situated within the last major meander of the Seine River before it reaches its estuary. "Bouafles" is located just upstream of a dam, in 'Les Andelys' (Fig. 1), in an oxbow lake located on the right bank of the Seine River. It corresponds to a young accretion area as indicated by the recent burial of trees. This undisturbed sampling area has remained grassland for 30 years, and gradual sediment deposition has occurred. Inhabitants confirmed that this site has been flooded until 2004 at least once a year. Eleven cores collected in this area between 2003 and 2008 indicated a continuous sedimentation during the last 60 years (see Le Cloarec et al., in press).

The second site (Muids), where the M1 core was collected, (Fig.1) is located on the same bank $12 \mathrm{~km}$ further downstream in the same meander of the Seine River. It is composed of four islands which experienced regular flooding during wintertime.

All cores were sampled April 9th, 2003 using an Eijkelkamp device equipped with a percussion drill bit (with 10-cm diameter and 1-m length). The stainless steel soil corer could be opened laterally thus allowing an immediate transfer of the core into a PVC tube and avoiding any metal contamination.

The 1-meter long core S01 was collected in at Pontoise-les-Noyon, March $23^{\text {rd }}, 2005$, in a meander of the Oise River (Fig. 1). The site is located in an annually flooded pasture downstream the city of Chauny. The core was sampled with the same equipment as the samples from Bouafles and Muids. The sampling site drains an area of $4044 \mathrm{~km}^{2}$ that was dominated by rural and low density urban areas. The Oise River basin has been industrialized since the beginning of the 1800's. This led to an increase of local urbanization beginning shortly after the Second World War and continuing until 1975 (Le Cloarec et al., in press). Today many Oise industrial plants are no longer in activity. The Saint Gobain (glass industry) plant in Chauny (Fig 1), situated a few km above the sampling site, is particularly interesting 
137 for this evaluation. This glass manufacture started its activity around 1665, employed large quantities of sulphuric acid and owned several lead chambers (7 in 1850, 22 in 1870).

140 In addition, treated wastewater issued from the Seine - Aval waste water treatment plant 141 (WWTP) at Achères (Fig. 1) was sampled during December 2006 (Pernet-Coudrier et al, 142 2008). The Seine - Aval WWTP is connected to $80 \%$ of the Paris conurbation area combined 143 sewers (9.5 million inhabitants).

\section{2. Core dating}

Details on the dating of the cores, such as depth profiles and sedimentation rates, are given in Le Cloarec et al. (in press).

The sediment cores are dated through the measurement of two radionuclides, ${ }^{137} \mathrm{Cs}-$ and ${ }^{210} \mathrm{~Pb}$. Both are strongly adsorbed on the fine fraction of the sediment (Wang and Cornett, 1993; Gil-García et al., 2009). Artificial ${ }^{137} \mathrm{Cs}$ is used as an event-tracer, whereas natural ${ }^{210} \mathrm{~Pb}$ provides the sediment age.

Both radionuclides are gamma emitters and can be analyzed in small quantities of sediments (ca. 50-100 g) without any previous chemical treatment. The sediments are dried at $115^{\circ} \mathrm{C}$, sieved $(<2 \mathrm{~mm})$, powdered and then placed into air-tight counting boxes. Counting was conducted during ca. $10^{5} \mathrm{~s}$ using Germanium gamma-ray detectors (High purity germanium - GeHP, N-type, coaxial model) at the Laboratoire des Sciences du Climat et de l'Environnement (Gif-sur-Yvette, France). Efficiencies and background of the detectors are controlled with internal soil and sediment standards, pure $\mathrm{KCl}$ samples, and IAEA standards (i.e., Soil-6, -135 and -375). Activity decay was corrected taking the sediment collection period into account.

${ }^{137} \mathrm{Cs}$, an artificial radionuclide $\left(\mathrm{t}_{1 / 2}=30\right.$ years $)$, was produced by the thermonuclear

162 bomb testing conducted between the 1950's and the 1980's (the maximum input occurred in 163 1964) and the Chernobyl accident in 1986. Measurement of the ${ }^{137}$ Cs activity in the sediment 164 allows one to distinguish three events: fallout due to the first significant input in the 165 atmosphere in 1954, maximum input in 1964 and fallout due to the Chernobyl accident in 166 1986. ${ }^{137}$ Cs stock stored in soils decreases by radioactive decay and fine sediment transfer to 167 the rivers. ${ }^{137} \mathrm{Cs}$ is easily identified in gamma spectrometry by a peak at $661 \mathrm{keV}$. The 168 uncertainty on measurements corresponds to ca. $0.5 \%$. The detection limit reaches $0.3 \mathrm{~Bq}^{\mathrm{kg}} \mathrm{g}^{-}$ 169 
${ }^{210} \mathrm{~Pb}$, a natural radionuclide $\left(\mathrm{t}_{1 / 2}=22.3\right.$ years $)$, is a decay product of ${ }^{238} \mathrm{U}\left(\mathrm{t}_{1 / 2}=4.510^{9}\right.$ years). ${ }^{238} \mathrm{U}$ decays through a series of short-lived nuclides (e.g. ${ }^{226} \mathrm{Ra},{ }^{222} \mathrm{Rn}$ ). ${ }^{222} \mathrm{Rn}$ is a gas that partly remains in situ, forming "supported" ${ }^{210} \mathrm{~Pb}$, and that partly escapes to the atmosphere, forming "excess" ${ }^{210} \mathrm{~Pb}$. Excess ${ }^{210} \mathrm{~Pb}$ is deposited on the soil surface via wet and dry fallout and strongly sticks to the soil particles. The ${ }^{210} \mathrm{~Pb}$ activity in "excess" is calculated by subtracting the supported activity (determined using a ${ }^{238} \mathrm{U}$ daughter, i.e. ${ }^{214} \mathrm{Bi}$ from the total activity of ${ }^{210} \mathrm{~Pb}$ (Bonté et al., 2000). The uncertainty of the measurements (ca. 10\%) is higher than that for ${ }^{137} \mathrm{Cs}$.

\subsection{Determination of lead concentration}

Details of the determination of lead concentration in totally digested sediment samples are given in Le Cloarec et al. (2009). Samples of about $100 \mathrm{mg}$ are dissolved by successive addition of $65 \% \mathrm{HNO}_{3}(3 \mathrm{~mL})$ and $30 \% \mathrm{HCl}(7 \mathrm{~mL})$ mixture, $65 \% \mathrm{HNO}_{3}$ and $40 \% \mathrm{HF}(5 \mathrm{~mL}$ each), and $65 \% \mathrm{HNO}_{3}$ and $69-72 \% \mathrm{HClO}_{4}(6 \mathrm{~mL}$ each) in Teflon vessels using a heating block (Digiprep, SCP Science). Ultra pure reagents were used (Normatom grade, VWR, France for $\mathrm{HNO}_{3}$, and $\mathrm{HCl}$, "for trace metal analyses", Baker, SODIPRO, France, for HF, and $\mathrm{HClO}_{4}$ ). The solutions were evaporated to dryness, retaken 3 times in $2 \mathrm{~mL}$ of $\mathrm{HNO}_{3}$ and then diluted with $50 \mathrm{~mL}$ of MilliQ water. Three different analytical techniques were used to determine the lead content: atomic absorption spectrometry (AAS), inductively coupled plasma - atomic emission spectrometry (ICP-AES) and inductively coupled plasma - mass spectrometry (ICP-MS) (Table 1). The accuracy of the Pb concentration determination was evaluated through the analysis of the certified reference material SL-1 (lake sediment, AIEA, Vienna, Austria). The obtained value, $36.6 \pm 2.0 \mathrm{mg} \cdot \mathrm{kg}^{-1}(\mathrm{n}=15)$, agreed with the certified concentration (37.7 mg. $\mathrm{kg}^{-1}$, certification interval: $30.3-45.5 \mathrm{mg} \cdot \mathrm{kg}^{-1}$ ). For all these methods, the lead concentration determination uncertainty was up to 5\%. The procedural "blank" contribution to the $\mathrm{Pb}$ concentration ranges from $0.06 \%$ for sediments with high $\mathrm{Pb}$ concentration up to $0.4 \%$ for sediments with low $\mathrm{Pb}$ content.

Fifty millilitres of bulk water samples (containing $50 \mathrm{mg} . \mathrm{L}^{-1}$ of dry residue) from the Seine-Aval WWTP were evaporated, the residues were totally dissolved with a mixture of $\mathrm{HNO}_{3}, \mathrm{HCl}, \mathrm{HF}$ and $\mathrm{HClO}_{4}$ (Normatom grade, VWR) in Teflon vessels using a heating block

(Digiprep, SCP Science). The solutions were evaporated and $2 \mathrm{ml}$ of $\mathrm{HNO}_{3}$ were added afterwards (addition and evaporation sequence repeated three times) and then diluted with 50 
$\mathrm{mL}$ of MilliQ water. $\mathrm{Pb}$ concentrations were determined by inductively coupled plasma quadrupole mass spectrometry ICP-QMS (X Series, ThermoElectron, France). Determination of $\mathrm{Pb}$ in the reference river water NIST-1640a (National Institute for Standards and Technology, Gaithersburg, USA) falls within $3 \%$ of the certified value $(n=9)$.

\subsection{Lead isotopic measurements.}

Lead isotope ratios $\left({ }^{208} \mathrm{~Pb} /{ }^{206} \mathrm{~Pb}\right.$ and $\left.{ }^{206} \mathrm{~Pb} /{ }^{207} \mathrm{~Pb}\right)$ were measured in the sediment solutions that were also used for lead concentration determinations and were made by ICPQMS (X Series, ThermoElectron, France), following the conditions defined in Gallon et al. (2006). The experimental conditions were: three channels reading; dwell time of $30 \mathrm{~ms} ; 100$ sweeps; 5 replicates per sample. Mass bias and drift of the isotope ratios were corrected based on repeated measurements of the $\mathrm{Pb}$ reference material NIST SRM-981 that were analysed between every three samples. The $2 \sigma$-errors of isotopic ratios are $0.23 \%$ for the ${ }^{206} \mathrm{~Pb} /{ }^{207} \mathrm{~Pb}$ and ${ }^{208} \mathrm{~Pb} /{ }^{206} \mathrm{~Pb}$ ratio. ${ }^{206} \mathrm{~Pb} /{ }^{207} \mathrm{~Pb}$ ratio of the blank corresponds to $1.168 \pm 0.003$ (lying in the range of the ${ }^{206} \mathrm{~Pb} /{ }^{207} \mathrm{~Pb}$ ratios of the samples). SRM-981 was also analysed as a sample $(\mathrm{n}=25)$ to control the bracketing correction. Values ${ }^{206} \mathrm{~Pb} /{ }^{207} \mathrm{~Pb}=1.0933 \pm 0.0015$ and ${ }^{208} \mathrm{~Pb} /{ }^{206} \mathrm{~Pb}=2.1681 \pm 0.0084$ were obtained. Certified values for the SRM-981 are

${ }^{206} \mathrm{~Pb} /{ }^{207} \mathrm{~Pb}=1.09333 \pm 0.00039$ and ${ }^{208} \mathrm{~Pb} /{ }^{206} \mathrm{~Pb}$ ratio $=2.1681 \pm 0.0008$. The lead isotopic composition of three samples from core B2 were also determined by thermal ionisation mass spectrometry (TIMS, Finnigan Mat 261 in LSCE), following the method described in Doucelance and Manhès, 2001. Even though the data obtained using TIMS are more precise than the data obtained using ICP-QMS, the results obtained with both instruments are consistent (see Fig. 2). ${ }^{206} \mathrm{~Pb} /{ }^{207} \mathrm{~Pb}$ and ${ }^{208} \mathrm{~Pb} /{ }^{206} \mathrm{~Pb}$ ratios were measured. The data are presented in the Supporting Information. Since both ratios are linearly correlated, only the ${ }^{206} \mathrm{~Pb} /{ }^{207} \mathrm{~Pb}$ ratio is used in the text.

\section{Figure 2}

\section{Results.}

Results are reported in Figure 3. Pb concentrations range from $76 \mathrm{mg} \cdot \mathrm{kg}^{-1}$ up to 460 mg.kg-1 in B2 (Bouafles), $73 \mathrm{mg} \cdot \mathrm{kg}^{-1}$ to $421 \mathrm{mg} \cdot \mathrm{kg}^{-1}$ in M1 (Muids), from $36 \mathrm{mg} \cdot \mathrm{kg}^{-1}$ to 342 mg. $\mathrm{kg}^{-1}$ in S01 (Oise) and from $41 \mathrm{mg} \cdot \mathrm{kg}^{-1}$ to $90 \mathrm{mg} \cdot \mathrm{kg}^{-1}$ in TR01 (Troyes). In all cores except that from Troyes (TR01) that starts in the 1970's, there is a peak of the $\mathrm{Pb}$ concentration 
around 1960. The concentration then decreases significantly. In the Oise core, this decrease is preceded by a regular strong increase that occurs between 1916 and 1960 .

Most of the $\mathrm{Pb}$ concentrations mentioned in the previous paragraph are above the natural background level. In the Seine River basin, $\mathrm{Pb}$ natural background is highly correlated to the clay content of the sediment, with a $\mathrm{Pb} / \mathrm{Al}$ ratio of $0.61 \mathrm{mg} / \mathrm{g}$ (Thévenot et al., 2007).

242 For the relatively Al-rich (fine grained) samples studied here, it corresponds to a $\mathrm{Pb}$ natural 243 background of about $27-40 \mathrm{mg} \mathrm{kg}^{-1}$. - the ${ }^{206} \mathrm{~Pb} /{ }^{207} \mathrm{~Pb}$ ratio is rather stable between 1920 to 1960 , ranging from $1.163 \pm 0.003$ up to $1.166 \pm 0.003$

- between 1960 and 1986/1989, the ${ }^{206} \mathrm{~Pb} /{ }^{207} \mathrm{~Pb}$ ratio decreases to $1.144 \pm 0.003$

- starting from $1986 / 1989$ up to the early 2000 's, the ${ }^{206} \mathrm{~Pb} /{ }^{207} \mathrm{~Pb}$ ratio increases up to $1.163 \pm$ 0.002 in 2000 and $1.166 \pm 0.003$ in 2003 .

After 2000 , the ${ }^{206} \mathrm{~Pb} /{ }^{207} \mathrm{~Pb}$ ratios in $\mathrm{B} 2$ and $\mathrm{M} 1$ are similar to that observed before 1960 , the $\mathrm{Pb}$ concentration however is much lower. This is due to the above mentioned general decrease of the $\mathrm{Pb}$ concentration.

In TR01, the ${ }^{206} \mathrm{~Pb} /{ }^{207} \mathrm{~Pb}$ ratio increases from $1.1521 \pm 0.0015$ in the 1970 's to $1.175 \pm$ $256 \quad 0.001$ in 2001. In $\mathrm{S} 01$, the ${ }^{206} \mathrm{~Pb} /{ }^{207} \mathrm{~Pb}$ ratio decreases from $1.181 \pm 0.002$ in 1916 to $1.166 \pm 0.001$ in 1952 (with the highest variation occurring between 1916 and 1927). In 1960, the highest $\mathrm{Pb}$ concentration is accompanied at the same time by a trend towards a higher ${ }^{206} \mathrm{~Pb} /{ }^{207} \mathrm{~Pb}$ ratio $\left({ }^{206} \mathrm{~Pb} /{ }^{207} \mathrm{~Pb}=1.173 \pm 0.003\right)$. This higher ${ }^{206} \mathrm{~Pb} /{ }^{207} \mathrm{~Pb}$ ratio then decreases until 1981 $\left({ }^{206} \mathrm{~Pb} /{ }^{207} \mathrm{~Pb}=1.1693 \pm 0.0015\right)$ and increases again $\left({ }^{206} \mathrm{~Pb} /{ }^{207} \mathrm{~Pb}=1.181 \pm 0.003\right.$ in 2003) whereas the $\mathrm{Pb}$ concentration decreases. Today's lead concentration in the Oise sediment corresponds to $36 \mathrm{mg} \cdot \mathrm{kg}^{-1}$. This value lies close to the geochemical background (27-40 mg.kg-1 ; Thévenot et al., 2007; Meybeck et al., 2007), while in 1960, concentration up to 342 $\mathrm{mg} \cdot \mathrm{kg}^{-1}$ was recorded (see supporting information). 
The Seine-Aval combined sewer system at Achères (SIAAP) collects $80 \%$ of the urban water originating from the Paris conurbation. The $\mathrm{Pb}$ concentration is $0.53 \pm 0.01 \mu \mathrm{g} . \mathrm{L}^{-1}$, this is in agreement with the detailed study of the Seine-Aval effluents composition by Buzier et al., (2006). The treated waste water, sampled during December 2006 (rainy period) is characterized by ${ }^{206} \mathrm{~Pb} /{ }^{207} \mathrm{~Pb}=1.154 \pm 0.002$ and may represent a mixture of lead originating from different sources (roof and road runoff, domestic and industrial wastewaters).

\section{Discussion.}

\subsection{Anthropogenic lead sources in the Seine river basin.}

Lead was widely used in Paris buildings long before leaded gasoline was introduced. Until now, the city of Paris has accumulated huge amounts of $\mathrm{Pb}$. The accumulated lead stock in the Seine river basin corresponds to 594,000 t from 1940 to 2000 (Thévenot et al., 2007). The major part of the anthropogenic lead stock is distributed as follows: 100,000 $\mathrm{t}$ in natural soils, 200,000 $\mathrm{t}$ in landfills, 110,000 $\mathrm{t}$ in pipes, tubes and roofs, 30,000 $\mathrm{t}$ in rivers and estuaries. The remaining 154,000 $\mathrm{t}$ are divided between different anthropogenic items (cables, glasses, accumulators, etc). The ability of these materials to contaminate the sediment varies from one material to another. In addition, it may be difficult to attribute a specific $\mathrm{Pb}$ signature to each of these items, because different ores and recycled lead may have been used at different period.

During the second part of the $18^{\text {th }}$ century, the majority of all $\mathrm{Pb}$ used in France was imported from Spain, French ores played only a minor role (Lestel, 2007). The major part of $\mathrm{Pb}$ imported by France from 1900-1914 came from Spain, Belgium-Luxemburg and United Kingdom, $\mathrm{Pb}$ extraction in French mines did not play an important role. Between World War 1 and World War 2, Spain, Mexico and Tunisia provided most of the $\mathrm{Pb}$ manufactured in France, the proportion of $\mathrm{Pb}$ furnished by French mines constantly decreased. After 1945, $\mathrm{Pb}$ was mainly imported from Morocco and Tunisia, more recently from the United State of America and the European Union. Today, all manufactured $\mathrm{Pb}$ in France originates from recycling.

$\mathrm{Pb}$ isotopic signatures in the environment are often interpreted as resulting from the mixing of three end-members: natural, industrial and gasoline $\mathrm{Pb}$. The definition and the characterisation of the local natural and leaded gasoline end-members are rather 
304 straightforward (Table 2). The local natural background signature $\left({ }^{206} \mathrm{~Pb} /{ }^{207} \mathrm{~Pb}=1.2007 \pm\right.$ 305 0.0011) was determined using a $8000 \mathrm{BP}-^{14} \mathrm{C}$ dated sediment (Elbaz-Poulichet et al., 1986).

306 The signature of additives for leaded gasoline $\left({ }^{206} \mathrm{~Pb} /{ }^{207} \mathrm{~Pb}=1.08 \pm 0.02\right)$ was determined 307 based on information from Octel Ltd at Paimboeuf, the only provider of leaded additives for 308 French gasoline (Véron et al., 1999).

Table 2

The determination of the nature and isotopic signature of the "industrial" end-member is more difficult. Industrial lead is characterized by an isotopic composition that is intermediate between the end-members of natural and leaded gasoline $\left({ }^{206} \mathrm{~Pb} /{ }^{207} \mathrm{~Pb} \approx 1.146-\right.$ 1.162; Monna et al., 2000; Véron et al., 1999; Widory et al., 2004) but at the same time it is characterized by significantly higher $\mathrm{Pb}$ concentrations. Carignan et al. (2005) suggest to use ${ }^{206} \mathrm{~Pb} /{ }^{207} \mathrm{~Pb}=1.154 \pm 0.003$ as the best estimate for the average French industrial atmospheric signature emission. Paradoxically, several heavy industries use $\mathrm{Pb}$ with isotopic signatures that are quite distinct from the "industrial" $\mathrm{Pb}$ signature (Carignan et al., 2005; Nageotte and Day, 1998; Véron et al., 1999). In this section, we discuss the possible sources and characteristics of the so-called "industrial" lead of the Seine basin and we compare it to values from previous studies. While $\mathrm{Pb}$ ores with different origins have been used throughout history, some prevailing ore isotopic signatures are relevant (Table 3):

European ores: the isotopic signature of most European ores (including French ores) falls in the range ${ }^{206} \mathrm{~Pb} /{ }^{207} \mathrm{~Pb} \approx 1.16-1.19$. Tunisian ores also lie in this range.

Rio Tinto: The isotopic signature of the Spanish ore $\left({ }^{206} \mathrm{~Pb} /{ }^{207} \mathrm{~Pb} \approx 1.1634 \pm 0.0001\right.$; Marcoux, 1998) distinctively falls on the low end of the European signature. Ores from Morocco are characterized by a similar signature.

Broken Hill: this Australian ore (together with other ores) is specifically used for the production of the leaded gasoline additives. Its low isotopic signature $\left({ }^{206} \mathrm{~Pb} /{ }^{207} \mathrm{~Pb} \approx 1.040 \pm\right.$ 0.001 ) is due to the old age of the crust from which the ore was formed. $\mathrm{Pb}$ signatures $\left({ }^{206} \mathrm{~Pb} /{ }^{207} \mathrm{~Pb} \approx 1.20 \pm 0.02\right.$; Rabinowitz et al., 2005). 
The similarity between the temporal evolution of the ${ }^{206} \mathrm{~Pb} /{ }^{207} \mathrm{~Pb}$ ratio of $\mathrm{B} 2$ and $\mathrm{M} 1$ (Fig.3) indicates that both profiles represent a global signal that characterizes the $\mathrm{Pb}$ isotopic signature after Paris and that they are not affected by local effects or sample heterogeneity. The minor difference in the concentration observed in the both profiles can be explained by different clay content (Ayrault et al., 2010).

It is possible to discriminate distinct $\mathrm{Pb}$ sources in a diagram where the ${ }^{206} \mathrm{~Pb} /{ }^{207} \mathrm{~Pb}$ ratio is plotted as a function of $1 /[\mathrm{Pb}]$ ratio, where $[\mathrm{Pb}]$ is the lead concentration $\left(\mathrm{mg}^{\mathrm{kg}} \mathrm{kg}^{-1}\right)$. In this diagram, all samples representing a mixing of 2 end-members fall on a straight line (Fig. $4)$.

\section{Figure 4}

Between 1927 and 1968, the lead isotopic signature of B2 and M1 plots in a narrow range that resembles Rio Tinto (and possibly Moroccan) ores, suggesting that these ores represent the most important $\mathrm{Pb}$ sources reaching the river. Significant contribution of other European or North American ores would raise the ${ }^{206} \mathrm{~Pb} /{ }^{207} \mathrm{~Pb}$ ratio above the observed values unless it is exactly compensated by addition of $\mathrm{Pb}$ from Broken Hill (see Table 3 for ores isotopic lead signatures). This hypothesis is unlikely because the oldest samples from Muids (1927) preceded the introduction of leaded gasoline (1931) and corresponded to a time when road traffic was marginal. Contamination of the 1930 sediments by younger sediments that come from the leaded gasoline period is unlikely, since:

- the similarity between the ${ }^{137} \mathrm{Cs}$ profile and the ${ }^{137} \mathrm{Cs}$ fallout history precludes mixing of the sediments (both ${ }^{137} \mathrm{Cs}$ and $\mathrm{Pb}$ are particle reactive);

- the $\mathrm{Pb}$ content is 3-4 times higher in ancient sediments than in the sediments from 1980;

- the in situ lead mobility is negligible (Alfonso et al., 2001; Kober et al., 1999).

Therefore the Rio Tinto signature probably represents the main lead contribution to the Seine River basin. This Rio Tinto ore signature may be the best source estimation for $\mathrm{Pb}$ that accumulated over centuries in the Seine River basin and may be called "historical" Parisian lead. Around 1850, English companies took the control of the major Spanish mines including Rio Tinto. Spain began to produce large quantities of lead, sold below the price of lead from British mines, the former biggest provider to Europe. From 1878, with the declining ore reserves in Britain, Spain became the major lead producer in Europe (Fletcher, 1991).

Surprisingly, the contribution of $\mathrm{Pb}$ from "heavy industries" characterized by a high ${ }^{206} \mathrm{~Pb} /{ }^{207} \mathrm{~Pb}$ ratio cannot be resolved in the average Seine River basin lead, although it can be 
371 detected locally (i.e., near the Eiffel Tower; Nageotte and Day (1998)). From 1968 to 372 1986/1989, the ${ }^{206} \mathrm{~Pb} /{ }^{207} \mathrm{~Pb}$ ratio decreases from 1.165 (Rio Tinto $\sim$ historical Parisian $\mathrm{Pb}$ ) to $3731.145 \pm 0.001$ (line 1 on Fig. 4). This decrease is clearly coupled with the raise of the leaded 374 gasoline emission in combination with the new environmental regulations which lead to a reduction of other than gasoline anthropogenic lead sources. In 1963, a directive on industrial effluents quality controls was published. Between 1960 and 1980 domestic wastewater treatment plants (WWTP) were gradually implemented. One important WWTP, the SeineAval combined sewer system at Achères, was operational at the end of the 70's. In addition to the reduction of industrial effluents, leaded gasoline reduction started in 1986 and leaded gasoline was completely banned after 2000. This mixing of historical Parisian lead with lead from leaded gasoline produces an "urban" lead signature (previously called "industrial") will be discussed in more details hereafter.

After 1989, the Seine River sediment signature evolves from the urban to the natural end-members (line 2, Fig. 4). Between 2000 and 2003, the ${ }^{206} \mathrm{~Pb} /{ }^{207} \mathrm{~Pb}$ ratio of the sediment is identical to the 1945-1968 sediments but the low $\mathrm{Pb}$ concentration in the 2000-2003 sediments produces a clear trend towards the natural end-member: lead in the Seine River sediment today represents a mixture of "urban" lead and natural background lead produced by soil erosion. The concentrations and isotopic signature observed for the most recent deposits at Bouafles and Muids are in agreement with the data observed at the Seine River mouth for the same period (Millot et al., 2004).

Previous studies have pointed out the decrease of the ${ }^{206} \mathrm{~Pb} /{ }^{207} \mathrm{~Pb}$ ratio in the time interval between 1900 and 1930 in the Lake Constance sediments (Germany) (Kober et al., 1999), in the French Alps lake sediments (Arnaud et al., 2004) and in the Mont Blanc ice record (Rosman et al., 2000). As in the case of the early signatures in the Seine sediments (M1), this early trend towards low ${ }^{206} \mathrm{~Pb} /{ }^{207} \mathrm{~Pb}$ ratios cannot be explained by leaded gasoline because leaded gasoline was only introduced on 1931 in France, Italy and Germany. In contrast the increase of industrial $\mathrm{Pb}$ uses, combined with the predominant use of Rio Tinto $\mathrm{Pb}$, results in a source of $\mathrm{Pb}$ that is characterized by a low ${ }^{206} \mathrm{~Pb} /{ }^{207} \mathrm{~Pb}$ ratio at the European scale.

TRO1 core

The samples (covering the 1970-2002 period) fall on the mixing line between urban lead and natural lead, very similar to the samples B2 and M1 after 1990. They lie closer to the natural end-member than the B2 and M1 samples because $\mathrm{Pb}$ contamination was less 
significant in this weakly urbanized and industrialized area. Nevertheless, the anthropogenic end-member in Troyes seems to consist of "urban" lead that is also present in B2 and M1.

S01 core

The Oise River had already been strongly polluted in 1916 by heavy industries as indicated by $\mathrm{Pb}$ concentrations above the natural background. The ${ }^{206} \mathrm{~Pb} /{ }^{207} \mathrm{~Pb}$ ratio rapidly increases several times and this may be caused by changes of the lead ores used by the industry and/or changes in the industrial activity or recycling. Samples from 1916 to 1952 fall on a mixing line between the natural and the Rio Tinto signature $\left({ }^{206} \mathrm{~Pb} /{ }^{207} \mathrm{~Pb}=1.1634 \pm\right.$ 0.0001). Between 1952 and 1960, there is a clear shift towards higher ${ }^{206} \mathrm{~Pb} /{ }^{207} \mathrm{~Pb}$ ratios $(\sim 1.17)$ in agreement with the use of European, Tunisian or north American ores together with recycled ores. This isotopic shift is associated with the highest $\mathrm{Pb}$ concentration in the core. Subsequently the concentrations decrease. And after 1976, the samples tend to be aligned onto the urban/natural mixing line, similar to the other sites for the last 35 years, suggesting that the industrial source characterized by high ${ }^{206} \mathrm{~Pb} /{ }^{207} \mathrm{~Pb}$ ratio has efficiently been removed.

The implementation of environmental regulations on industrial waste discharge to the river in the 1970's and the decrease of the industrial activity on the Chauny site, associated to the fact that an industrial discharge is a point source that is easier to mitigate than diffuse urban sources, have contributed to the improve the quality of the Oise River environment. The Oise River represents a successful example of river resilience towards water pollution.

\subsection{Industrial lead signature revisited.}

We showed in the previous section that systematic variations of the $\mathrm{Pb}$ isotopic signature occurred over the last 75 years in a large urbanised river basin. Until now, these changes were not observed because suitable archives were lacking. Our investigation shades new light on the "industrial" lead signature. Until now the industrial lead signature in France was estimated based on untreated and treated urban wastewater from South France (Monna et al. 2000) and urban incinerators (Cloquet et al., 2006; Widory et al., 2004) that were collected between 1992 and 2001. The observed signatures in this study range from ${ }^{206} \mathrm{~Pb} /{ }^{207} \mathrm{~Pb}=1.146$ up to ${ }^{206} \mathrm{~Pb} /{ }^{207} \mathrm{~Pb}=1.162$. Over this short time span and for these very different sites, the scattering of the data was so high that no significant temporal evolution could be resolved. The significantly lower ${ }^{206} \mathrm{~Pb} /{ }^{207} \mathrm{~Pb}$ ratio for indoor Parisian dust (1971-1981) and roadside 
atmospheric particles (1974): $1.120 \pm 0.001$ and $1.101 \pm 0.001$, respectively, registered by Elbaz-Poulichet et al. (1986) are probably due to sample contamination by leaded gasoline. enters the river and that the waste waters combine most contaminant sources of lead for the river (roofs, pipes, accumulators, and oxide-containing glasses), the signature of the waste waters constitutes the urban lead signature for the river sediments. Indeed the urban lead signature defined by the isotopic signature of the WWTP Seine -Aval at Achères sewage $\left({ }^{206} \mathrm{~Pb} /{ }^{207} \mathrm{~Pb}=1.154 \pm 0.002\right)$ is not significantly different from the signature of the three major Parisian municipal solid waste incinerators (1.1550 \pm 0.0005 ; Widory, 2004), the leaded paint chips and the tap water contaminated by lead pipes (Table 2).

The urban signature measured nowadays after the complete stop of leaded gasoline in $2000\left({ }^{206} \mathrm{~Pb} /{ }^{207} \mathrm{~Pb}=1.154 \pm 0.002\right)$ is significantly different from the measured signature in the Seine sediments before $1960\left({ }^{206} \mathrm{~Pb} /{ }^{207} \mathrm{~Pb}=1.167 \pm 0.002\right)$. This suggests that leaded gasoline created an "in-depth" contamination of the environment. As argued in the previous sections, the lead accumulated in the Parisian conurbation is largely dominated by the Rio Tinto ores signature. This domination is enforced by recycling. The contribution of recycled lead in manufacture is significant in France: 50\% in 1950 increasing to $70 \%$ in 2000 (Lestel, 2007). Today all manufactured $\mathrm{Pb}$ that is used in France comes from recycling. The large amount of lead accumulated in the urban structures tends to buffer the isotopic signature in the river which is marginally shifted by the leaded gasoline in depth imprint.

The "industrial lead" denomination is ambiguous because several heavy industries in the Seine basin and in France show $\mathrm{Pb}$ isotopic signatures that are distinct from the "industrial $\mathrm{Pb}$ " (see section "TR01 core"). The lead signature of the Oise river sediment, directly issued from industrial activities, is quite distinct $\left({ }^{206} \mathrm{~Pb} /{ }^{207} \mathrm{~Pb}=1.174 \pm 0.003\right)$. Therefore the denomination "industrial" attributed to all the signatures but gasoline additives may be abusive. In order to prevent any confusion, we use the term "urban" $\left({ }^{206} \mathrm{~Pb} /{ }^{207} \mathrm{~Pb}=1.154 \pm\right.$ 0.002) for the most common Parisian $\mathrm{Pb}$ signatures and "heavy industries" for the relevant industries.

\subsection{Impact of leaded gasoline of the Seine sediment contamination.}

The leaded gasoline represents a small part of the total $\mathrm{Pb}$ used in France $(5 \%$ in the early 1970's: 14,000 t for leaded additives over 271,000 t in total in 1974) (Meybeck et al, 
2007). At the same time leaded gasoline represents almost $90 \%$ of the anthropogenic atmospheric lead emission (Ferrand et al., 1999), thus raising the possibility that the Seine river catchment suffers from a wide contamination by road traffic. The present data can be used to evaluate the contribution of the leaded gasoline to the Seine contamination.

The maximum impact of the leaded gasoline in the Seine sediment contamination was reached in $1986 / 1989$ (Fig. 3), when the ${ }^{206} \mathrm{~Pb} /{ }^{207} \mathrm{~Pb}$ ratio was at its lowest value $(1.146 \pm$ 0.002). Considering that the lead was a mixture of leaded gasoline $\left({ }^{206} \mathrm{~Pb} /{ }^{207} \mathrm{~Pb}=1.08 \pm 0.02\right)$ and historical lead whose signature is defined by the oldest sedimentary deposits $\left({ }^{206} \mathrm{~Pb} /{ }^{207} \mathrm{~Pb}\right.$ $=1.165 \pm 0.002$ in 1943 (B2)), as shown by the mixing line 1 on Fig. 4, the fraction of lead issued from the gasoline ( $\left.f_{\text {gazoline }}\right)$ in the Seine River sediments is given by Equation 1:

$$
f_{\text {gazol i } n \bar{e}}=\frac{\left(\frac{{ }^{206} P b}{{ }^{207} P b}\right)_{\text {sample }}-\left(\frac{{ }^{206} P b}{{ }^{207} P b}\right)_{\text {hi storica }}}{\left(\frac{{ }^{206} P b}{{ }^{207} P b}\right)_{\text {gasol ine }}-\left(\frac{{ }^{206} P b}{{ }^{207} P b}\right)_{\text {historic }}} \text { 1) }
$$

From Eq. 1, we calculate that the fraction of lead issued from the gasoline in the Seine River sediments is $23 \pm 6 \%$ when the impact of the leaded gasoline is on the climax. The choice of the value for the "urban" signature strongly affects the calculated $\mathrm{Pb}$ fraction originating from gasoline. If we had assumed as in previous studies, that the ${ }^{206} \mathrm{~Pb} /{ }^{207} \mathrm{~Pb}$ ratio of the urban/industrial end-member is 1.155 , the calculated contribution of leaded gasoline would have been only $13 \pm 4 \%$.

In any case, the contribution of leaded gasoline to the Seine basin is significantly more important than its contribution to the lead used in France in 1986 ( $<5 \%$ in Lestel, 2007). This implies that $\mathrm{Pb}$ from leaded gasoline has a larger environmental mobility than other $\mathrm{Pb}$ sources. This is consistent with sequential extraction experiments on soils and soakaway sediments (Kumar et al., 2009). This is not surprising because Pb from combustion of leaded gasoline is directly emitted in the atmosphere whereas the other sources of lead tend to be stored or recycled rather than being directly dispersed into the environment.

Although $\mathrm{Pb}$ from leaded gasoline is preferentially transported by the Seine River compared to other sources, it does not represent the majority of the lead present in the sediments. As discussed in more detail in section 4.2., important stocks of $\mathrm{Pb}$ have been 
501 accumulated in the Paris conurbation (soils, buildings, pipes) and their slow release in the

502 environment produces most of the $\mathrm{Pb}$ contamination. Leaks also occur in rural areas. The

503 residence time of particles on soil reaches up to 30,000 years at Andrésy, a site located between the Seine-Aval WWTP and Bouafles (Le Cloarec et al., 2007). The strong affinity of $\mathrm{Pb}$ for organic matter is responsible for atmospheric lead immobilisation on the uppermost soil layer (Kabata-Pendias and Pendias 1992). Much shorter residence time is found for particles on non-permeable soils, because of runoff washing out.

The stock of anthropogenic lead in the soils of Paris area is estimated to lie close to 143,000 t (Saby et al., 2006). This stock includes the fallouts issued from the leaded gasoline combustion. Therefore, most $\mathrm{Pb}$ issued for the leaded gasoline combustion did not (yet) reach the river. The lead issued from gasoline that is seen in the Seine sediment around 1986 was probably brought to the river by road and roof runoff. The direct contamination of $\mathrm{Pb}$ from leaded gasoline in the atmosphere compared to the other sources of $\mathrm{Pb}$ also explains that the fraction of $\mathrm{Pb}$ from leaded gasoline is lower in the urban lead characterised in the hydrosystem $\left({ }^{206} \mathrm{~Pb} /{ }^{207} \mathrm{~Pb}=1.146 \pm 0.002\right)$ than in Parisian aerosols samples approximately at the same period $\left({ }^{206} \mathrm{~Pb} /{ }^{207} \mathrm{~Pb}=1.1187-1.1260\right.$ in 1989; Véron et al., 1999).

\subsection{Lead sources today.}

Since runoff has probably washed out the labile lead source (i.e., the leadcontaminated particles on non-permeable surfaces) and since the direct inputs of lead from the heavy industries are very low, the lead concentration today in the Seine river sediments represents a mixture of natural and urban lead (line 2 in Fig. 4). Considering the respective signature of the natural lead $\left({ }^{206} \mathrm{~Pb} /{ }^{207} \mathrm{~Pb}=1.2007 \pm 0.0011\right)$ and the signature of urban lead $\left({ }^{206} \mathrm{~Pb} /{ }^{207} \mathrm{~Pb}=1.154 \pm 0.002\right)$ (line 2 in Fig. 4), we calculate that the lead today $\left({ }^{206} \mathrm{~Pb} /{ }^{207} \mathrm{~Pb}=\right.$ $1.166 \pm 0.004)$ is constituted of $30 \%$ of natural lead and $70 \%$ of urban lead. This result is compatible with the concentration data, as the natural background concentration is $27-40 \mathrm{mg}$ $\mathrm{kg}^{-1}$ and the total lead sediment concentration is $77 \mathrm{mg} \mathrm{kg}^{-1}$. If the $\mathrm{Pb}$ concentration in the urban end-member is much higher than in the natural one, it corresponds to $34 \%$ of natural lead and $66 \%$ of urban lead. Moreover, these findings are also consistent with the study by Thévenot et al. (2007). These authors evaluate the sources and pathways budget for seven metals including lead in the Seine River basin for the period, $1994-2003$. The total lead inputs to the river reached $65 \mathrm{t} \mathrm{y}^{-1}, 14 \mathrm{t} \mathrm{y}^{-1}$ come from erosion (22\%). The anthropogenic 
534 sources of lead to the river $\left(51 \mathrm{t} \mathrm{y}^{-1}\right)$ are mainly located in urban areas $\left(48 \mathrm{t}^{-1}\right)$. Thévenot et 535 al. (2007) estimated urban sources to contribute to $74 \%$ of the lead input to the river, the urban contribution corresponds to $70 \%$ as deduced from the isotopic data.

\section{Conclusion.}

Most studies on the $\mathrm{Pb}$ isotopic signature in the Paris area or in France have focussed until today on aerosols, incinerator fumes and waste water treatment plants sewage collected between 1970 and 2005. The present study provides the first continuous record of the $\mathrm{Pb}$ isotopic signature for the Paris conurbation between 1930 and 2003. These are the first records that monitor the temporal evolution of riverine $\mathrm{Pb}$ contamination in a large urbanised area. In particular, this study allows us to characterize the average isotopic signature of $\mathrm{Pb}$ accumulated in the Paris conurbation until 1960 during the "pre-leaded gasoline" period, hence defining the reference value that is used to determine the contribution of leaded gasoline after 1960. This average pre-gasoline signature corresponds to the Rio Tinto ore that has been highly exploited since the middle of the $19^{\text {th }}$ century. As a result, we show that during the 1980's, the contribution of leaded gasoline to the Seine River contamination (around 24\%) exceeds by far the contribution of the leaded gasoline additives use to the global flux of $\mathrm{Pb}$ entering the Seine basin (5\% or less). Therefore, the information brought by the ${ }^{206} \mathrm{~Pb} /{ }^{207} \mathrm{~Pb}$ ratio will contribute to revaluate and improve the $\mathrm{Pb}$ fluxes in the Seine River 554 basin.

The impact of this study goes far beyond the Seine River basin. As the Rio Tinto ore has a ${ }^{206} \mathrm{~Pb} /{ }^{207} \mathrm{~Pb}$ ratio that is lower than most lead ores used in Europe earlier than 1800 , increasing use of the Rio Tinto ore during the $19^{\text {th }}$ century could account for the general decrease of the ${ }^{206} \mathrm{~Pb} /{ }^{207} \mathrm{~Pb}$ ratio during the $19^{\text {th }}$ and early $20^{\text {th }}$ century that is observed in various European archives (ice core, lake sediments, peat bog) which remained unexplained until now because it occurred before the "leaded gasoline era".

Acknowledgements. We thank G. Varrault and B. Pernet-Coudrier for their help for the collection of WWTP sediment, and O. Evrard for mapping and land cover data collection. J.M. Mouchel is thanked for his active participation to the sediment core collection and his continuous support to this work. We thank the 2 anonymous reviewers for their thoughtful 
568 comments. This work has been made possible thanks to funding from the Piren-Seine 569 programme coordinated by J.-M. Mouchel. This is the LSCE contribution number 4517.

570

571 In Supporting Information are reported the lead concentration and lead isotope composition 572 for the four cores.

573 
Alfonso, S., Grousset, F., Massé, L., Tastet, J.P. A European lead isotope signal recorded from 6000 to 300 years BP in coastal marshes (SW France). Atmos. Environ. 35 (2001) 3595-605.

Arnaud, F., Revel-Rolland, M., Bosch, D., Winiarski, T., Desmet, M., Tribovillard, N., Givelet, N. A 300 year history of lead contamination in northern French Alps reconstructed from distant lake sediment records. J. Environ. Monit. 6 (2004) 448-56. Arribas, A., Tosdal, R.M. Isotopic composition of $\mathrm{Pb}$ in ore deposits of the Betic Cordillera, Spain: Origin and relationship to other European deposits. Econ. Geol. 88 (1994) 107493.

Ayrault, S., Rianti, C., Evrard, O., Lefèvre, I., Bonté, P. Silver and thallium historical trends in the Seine River basin. J. Environ. Monit. 12 (2010) 2177-85. doi:10.1039/C0EM00153H.

Bonté, P., Mouchel, J.M., Thomas, A.J., Le Cloarec, M.F., Dumoulin, J.P., Sogon, S., Tessier, L. Buffering of suspended sediment transport in lowland river during low water stages: quantification in river Seine using environmental radionuclides. Acta Geol. Hisp. 35 (2000) 339-55.

Buzier ,R., Tusseau-Vuillemin, M.H., Martin dit Meriadec, C., Rousselot, O., Mouchel, J.M. Trace metal speciation and fluxes within a major French wastewater treatment plant: Impact of the successive treatments stages. Chemosphere 65 (2006) 2419-26.

Carignan, J., Libourel, G., Cloquet, C., Le Forestier, L. Lead Isotopic Composition of Fly Ash and Flue Gas Residues from Municipal Solid Waste Combustors in France : Implications for Atmospheric Lead Source Tracing. Environ. Sci. Technol. 39 (2005) 2018-24.

Chillrud, S.N., Bopp, R.F., Ross, J.M., Chaky, D.A., Hemming, S,, Shuster, E.L., Simpson, H.J,, Estabrooks, F. Radiogenic lead isotopes and time stratigraphy in the Hudson River, New York. Water, Air, Soil Pollut. (2003) 469-82.

Cloquet, C., Carignan, J., Libourel, G. Atmospheric pollutant dispersion around an urban area using trace metal concentrations and $\mathrm{Pb}$ isotopic compositions in epiphytic lichens. Atmos. Environ. 40 (2006) 574-87.

Cuming, G.L., Kesler, S.E., Krstic, D. Isotopic composition of lead in Mexican mineral deposits. Econ. Geol. 74 (1979) 1395-407.

Dejonghe, L., Boulègue, J., Demaiffe, D., Létolle, R. Isotope geochemistry (S, C, O, Sr, Pb) of the Chaudfontaine mineralization (Belgium). Miner. Deposita 24 (1989) 132-40.

Deloule, E., Allègre, C.J,. Doe, B.R. Lead and sulfur isotope microstratigraphy in galena crystals from Mississippi valley-type deposits. Econ. Geol. 81 (1986) 1307-21.

De Vleeschouwer, F., Gérard, L., Goormaghtigh, C., Mattielli, N., Le Roux, G., Fagel, N. Atmospheric lead and heravy metal pollution records from a Belgian peat bog spanning the last two millennia: Human impact on a regional to global scale. Sci. Total Environ. 377 (2007) 282-95.

Doucelance, R., Manhès, G. Reevaluation of precise lead isotope measurements by thermal ionization mass spectrometry: comparison with determinations by plasma source mass spectrometry. Chem. Geol. 176 (2001) 361-77.

Elbaz-Poulichet, F., Holliger, P., Martin, J.M,, Petit, D. Stable lead isotopes ratios in major French rivers and estuaries. Sci. Total Environ. 54 (1986) 61-76.

Fletcher, S. Lead Mining in Pain in the 19th century: Spanish industry or British adventure? Bulletin Peak District Mines Historical Society 11(4) (1991) 195-202.

Ferrand, J.L., Hamelin, B., Monaco, A. Isotopic tracing of anthropogenic $\mathrm{Pb}$ inventories and sedimentary fluxes in the Gulf of Lions (NW Mediterranean sea). Cont. Shelf Res. 19 (1999) 23-47. 
Gallon, C., Tessier, A., Gobeil, C. Historical perspective of industrial lead emissions to the atmosphere from a Canadian Smelter. Environ. Sci. Technol. 40 (2006) 741-747.

Gil-García, C., Rigol, A., Vidal, M. New best estimates for radionuclide solid-liquid distribution coefficients in soils, Part 1: radiostrontium and radiocaesium. J. Environ. Radioact. 100 (2009) 690-6.

Kabata-Pendias, A., Pendias, H. Trace Elements in Soils and Plants, 2nd ed. CRC Press, Boca Raton, 1992.

Kesler, S.E., Cumming, G.L,, Krstic, D., Appold, M.S. Lead Isotope Geochemistry of Mississippi Valley-Type Deposits of the Southern Appalachians. Econ. Geol. 89 (1994) 307-21.

Kober, B., Wessels, M., Bollhöfer, A., Mangini, A. Pb isotopes in sediments of Lake Constance, Central Europe constrain the heavy metal pathways and the pollution history of the catchment, the lake and the regional atmosphere. Geochim. Cosmochim. Acta 63, 9 (1999) 1293-1303.

Kumar, M., Furumai, H., Kurisu, F., Kasuga, I. Understanding the partitioning processes of mobile lead in soakaway sediments using sequential extraction and isotope analysis. Water Sci. Technol. 60.8 (2009) 2085-2091.

Krahn, L., Baumann, A. Lead isotope systematics of epigenetic lead-zinc mineralization in the western part of the Rheinisches Schiefergebirge, Germany. Miner. Deposita 31 (1996) 225-237.

Laurensot, F. Importance de la qualité de l'eau sur l'imprégnation saturnine. Identification des sources prépodérantes d'exposition au plomb. Utilisation de l'isotopie. Rapport d'étude. LHRSP, Agence de l'eau Seine-Normandie. (2001) 52 p.

Large, D., Schaeffer, R., Höhndorf, A. Lead Isotope Data from Selected Galena Occurrences in the North Eifel and North Sauerland, Germany. Miner. Deposita 18 (1983) 235-43.

Le Cloarec, M.F., Bonté, P., Mouchel, J.M., Lefèvre, I., Colbert, S. Distribution of ${ }^{210} \mathrm{~Pb},{ }^{7} \mathrm{Be}$ and ${ }^{137} \mathrm{Cs}$ in watersheds of different scales in the Seine basin: inventories and residence times. Sci. Total Environ. 375 (2007) 125-39.

Le Cloarec, M.F., Bonté, P., Lestel, L., Lefèvre, I., Ayrault, S. Sedimentary record of metal contamination in the Seine River during the last century. Phys. Chem. Earth, in press.

Lestel, L. Le cycle du plomb. 2007; hal-00199344, version 1, http://hal.archivesouvertes.fr/hal-00199344/en/ (in French).

Meybeck, M., Lestel, L., Bonté, P., Moilleron, R., Colin, J.L., Rousselot, O., et al. Historical perspective of heavy metals contamination $(\mathrm{Cd}, \mathrm{Cr}, \mathrm{Cu}, \mathrm{Hg}, \mathrm{Pb}, \mathrm{Zn})$ in the Seine River basin (France) following a DPSIR approach (1950-2005). Sci. Total Environ. 375 (2007) 204-31.

Millot, R., Allègre, C.J., Gaillardet, J., Roy, S. Lead isotopic systematics of major river sediments: a new estimate of the $\mathrm{Pb}$ isotopic composition of the Upper Continental Crust. Chem. Geol. 203 (2004) 75- 90

Monna, F., Clauer, N., Toulkeridis, T., Lancelot, J. R. Influence of anthropogenic activity on the lead isotope signature of Thau Lake sediments (southern France): origin and temporal evolution. Appl. Geochem. 15 (2000) 1291-1305.

Nageotte, S., Day, J.P. Lead concentrations and isotope ratios in street dust determined by electrothermal atomic absorption spectrometry and inductively coupled plasma mass spectrometry. Analyst 123 (1998) 59-62.

Pernet-Coudrier, B., Clouzot, L., Varrault, G., Tusseau-Vuillemin, M.H., Verger, A., Mouchel, J.M. Dissolved organic matter from treated effluent of a major wastewater treatment plant: characterization and influence on copper toxicity. Chemosphere 73 (2008) 593-9. 
Marcoux, E. Lead isotope systematics of the giant massive sulphide deposits in the Iberian Pyrite Belt. Miner. Deposita 33 (1998) 45-58.

Rabinowitz, M.B. Lead isotopes in soils near five historic American lead smelters and refineries. Sci. Total Environ. 346 (2005) 138- 48.

Rosman, K.J.R., Ly, C., Van de Velde, K., Boutron, C.F. A two century record of lead isotopes in high altitude Alpine snow and ice. Earth Planet. Sci. Lett. 176 (2000) 41324.

Saby, N., Arrouays, D., Boulonne, L., Jolivet, C., Pochot, A. Geostatistical assessment of Pb in soil around Paris, France. Sci. Total Environ. 367 (2006) 212-21.

Sahnoun, O., Schärer, U., Added, A., Fernex, F., Abdeljaoued, S. Metal origin and Pb isotopes in water of the mine-draining Mejerda river system, north Tunisia. Geochem.: Explor. Environ. Anal. 9 (2009) 369-80.

Shotyk, W., Weiss, D., Appleby, P., Cheburkin, A., Frei, R., Gloor, M., Kramers, J., Reese, S., Van Der Knapp, W. History of atmospheric lead deposition since 12,370 14C yr BP from peat bog, Jura Mountains, Switzerland. Science (1998) 281, 1635-40.

Soster, F.M., Matisoff, G., Whiting, P.J., Fornes, W., Ketterer, M., Szechenyi, S. Floodplain sedimentation rates in an alpine watershed determined by radionuclide techniques. Earth Surf. Proces. Landforms 32 (2007) 2038-51.

Thévenot, D.R., Moilleron, R., Lestel, L., Gromaire, M.C., Rocher, V., Cambier, P., Bonté, P., Colin, J.L., de Pontevès, C., Meybeck, M. Critical budget of metal sources and pathways in the Seine River basin (1994-2003) for Cd, Cr, Cu, Hg, Ni, Pb and Zn. Sci. Total Environ. 375 (2007) 180-203.

Townsend, A.T., Yu, Z., McGoldrick, P., Hutton, J.A. Precise lead isotope ratios in Australian galena samples by high resolution inductively coupled plasma mass spectrometry. J. Anal. At. Spectrom. 13 (1998) 809-13.

Véron, A., Flament, P., Bertho, M.L., Alleman, L., Flegal, R., Hamelin, B. Isotopic evidence of pollutant lead sources in Nothwestern France. Atmos. Environ. 33 (1999) 3377-88.

Wang, K., Cornett, R.J. Distribution coefficients of ${ }^{210} \mathrm{~Pb}$ and ${ }^{210} \mathrm{Po}$ in laboratory and natural aquatic systems. J. Paleolimnol. 9 (1993) 179-88.

Widory, D., Roy, S., Le Moullec, Y., Toupil, G., Cocherie, A., Guerrot, C. The origin of atmospheric particles in Paris: a view through carbon and lead isotopes. Atmos. Environ. 38 (2004) 953-61.

Widory, D. Development of a method for characterising contributions of point sources to atmospheric emissions of particles using a multi-isotopic approach: Application to the urban area of Paris. Report BRGM/RP-53335-FR (2004). 


\section{Tables}

712 Table 1. Details on the four analysed cores sampled in the Seine River basin.

Table 3. ${ }^{206} \mathrm{~Pb} /{ }^{207} \mathrm{~Pb}$ signature of lead in ores potentially imported by France from 1900 to 718

\section{Figures}

721 Figure 1. Core sampling sites (black circles) in the Seine River basin. The major waste water 722 treatment plant (WWTP) Seine Aval at Achères, downstream Paris, is indicated with a black 723 square. The lined area represents the Paris conurbation that concentrates $80 \%$ of the Seine 724 River basin population (14 million inhabitants).

Figure 2. Lead isotopic composition $\left({ }^{206} \mathrm{~Pb} /{ }^{207} \mathrm{~Pb}\right)$ by thermal ionisation mass spectrometry (TIMS) and inductively coupled plasma - mass spectrometry (ICP-QMS) in three sediment

728 samples ( $2 \sigma$ error bars).

730 Figure 3. Lead concentration and isotope ratio in the dated depth profiles in four cores in the Seine River basin.

733 Figure 4. Evolution of the lead isotopic composition $\left({ }^{206} \mathrm{~Pb} /{ }^{207} \mathrm{~Pb}\right)$ in the Seine River basin 734 sediment: influence of geochemical background, leaded gasoline and heavy industries. 


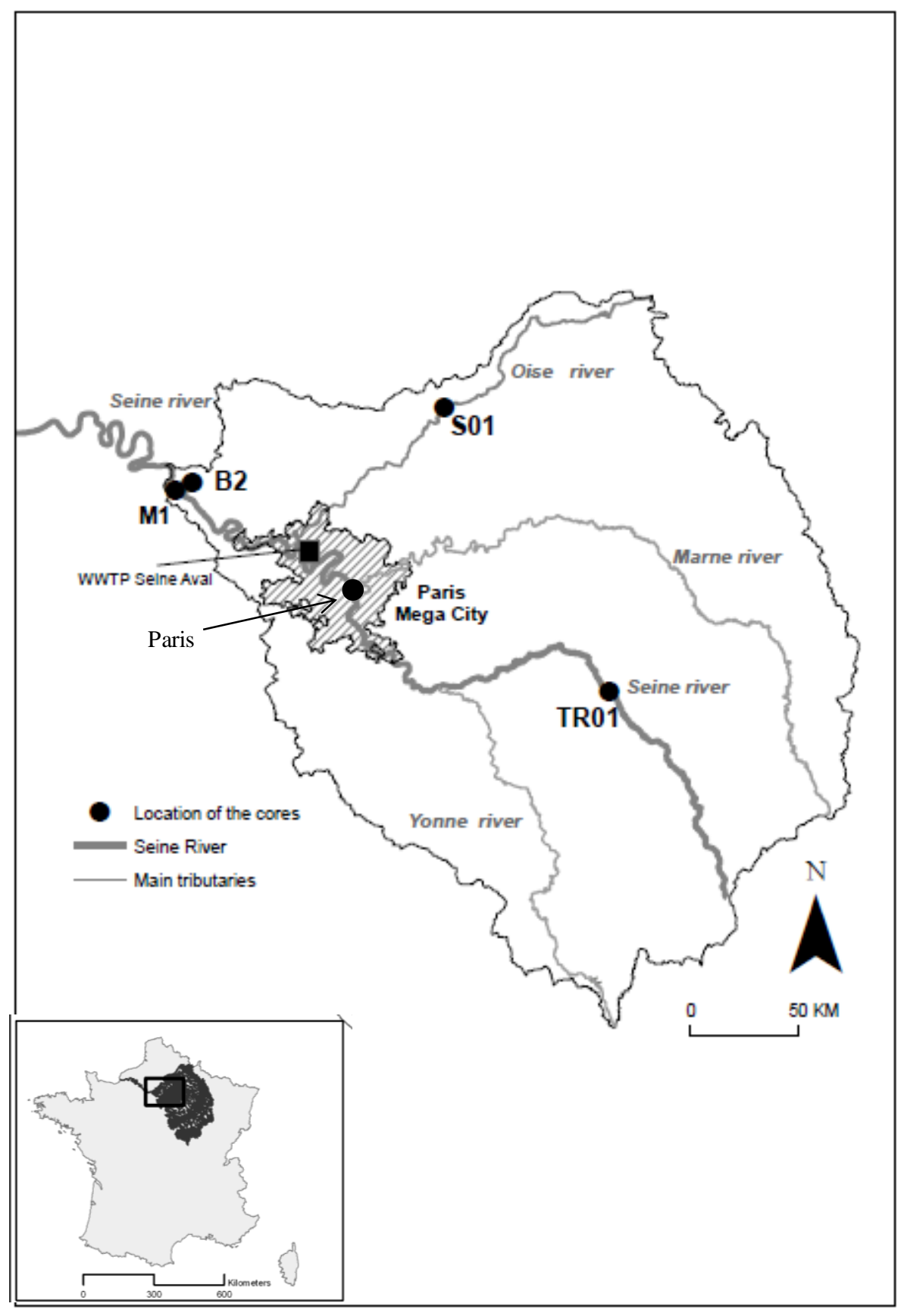




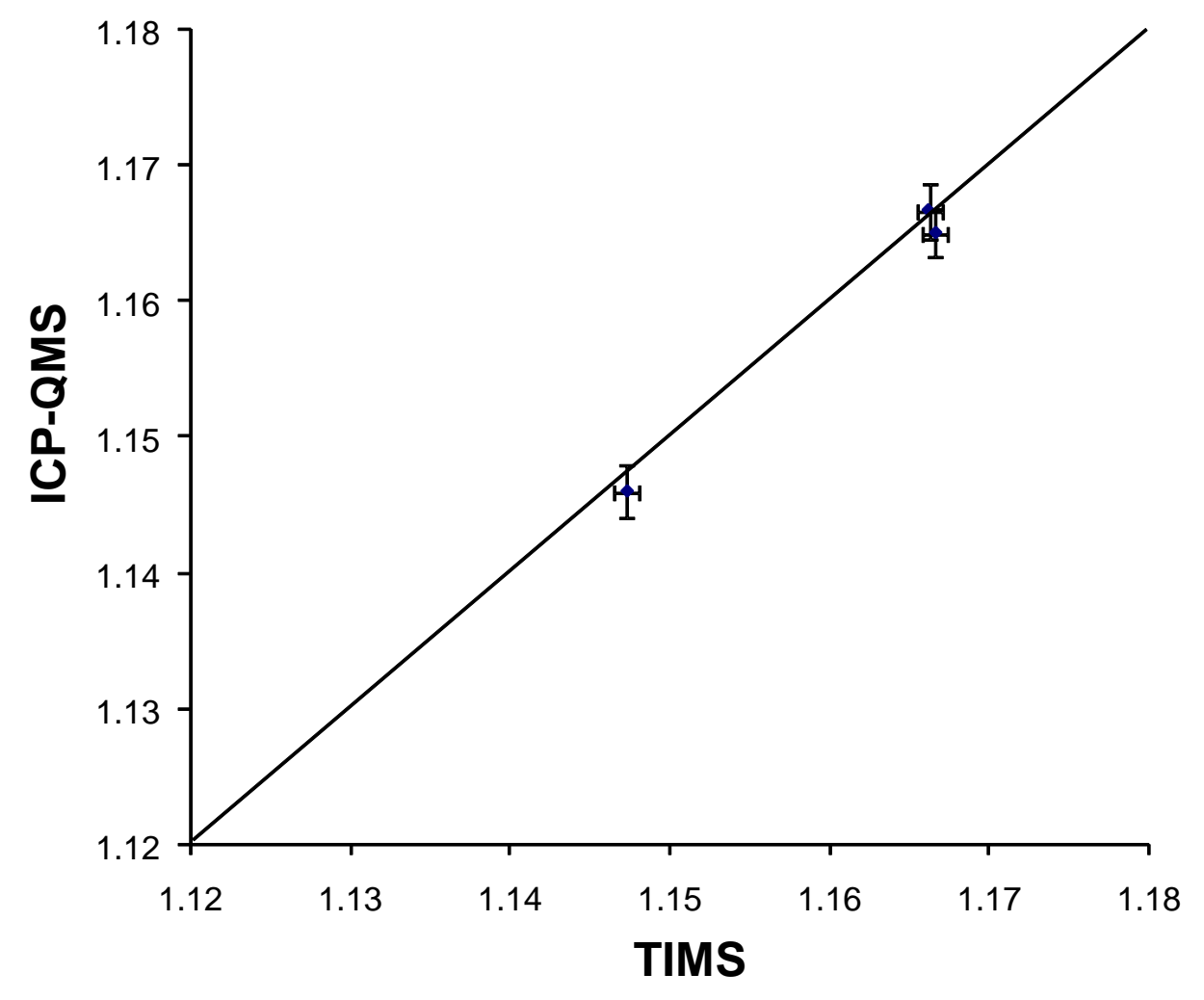

Figure 2. Lead isotopic composition $\left({ }^{206} \mathrm{~Pb} /{ }^{207} \mathrm{~Pb}\right)$ by thermal ionisation mass spectrometry (TIMS) and inductively coupled plasma - mass spectrometry (ICP-QMS) in three sediment samples ( $2 \sigma$ error bars). 


$$
{ }^{206} \mathrm{~Pb} /{ }^{207} \mathrm{~Pb}
$$

$\begin{array}{llllll}1.14 & 1.15 & 1.16 & 1.17 & 1.18 & 1.19\end{array}$

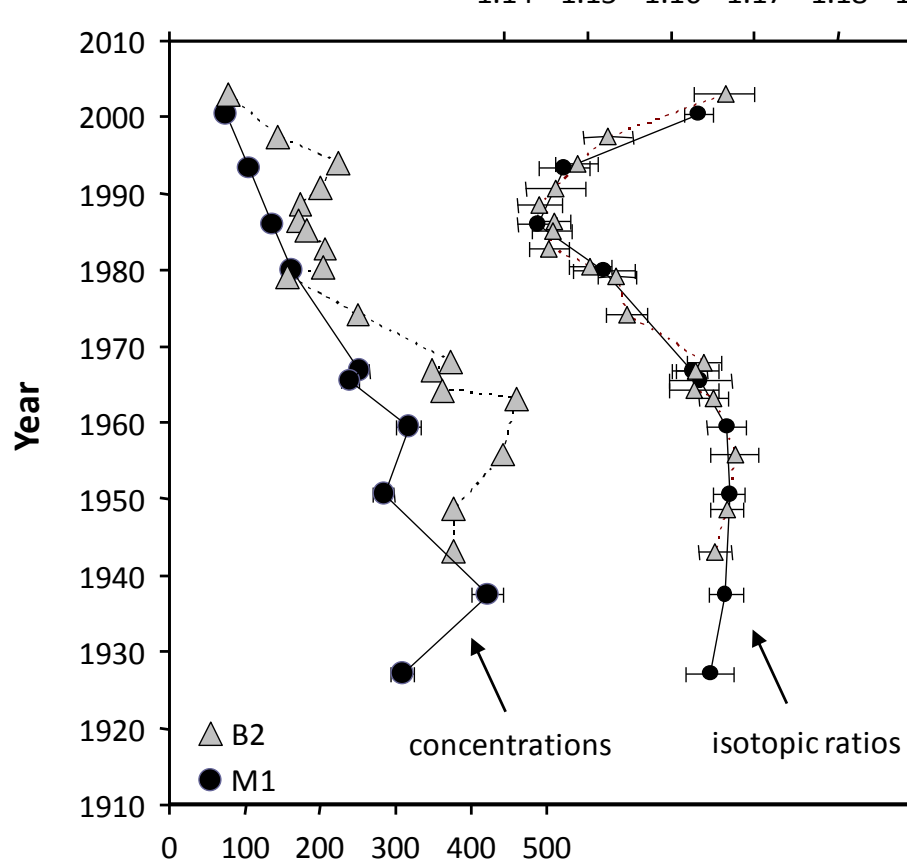

$\begin{array}{llllll}0 & 100 & 200 & 300 & 400 & 500\end{array}$

Lead concentration $(\mu \mathrm{g} / \mathrm{g})$
${ }^{206} \mathrm{~Pb} /{ }^{207} \mathrm{~Pb}$

${ }^{206} \mathrm{~Pb} /{ }^{207} \mathrm{~Pb}$

$\begin{array}{llllll}1.14 & 1.15 & 1.16 & 1.17 & 1.18 & 1.19\end{array}$

$\begin{array}{llllll}1.14 & 1.15 & 1.16 & 1.17 & 1.18 & 1.19\end{array}$ 


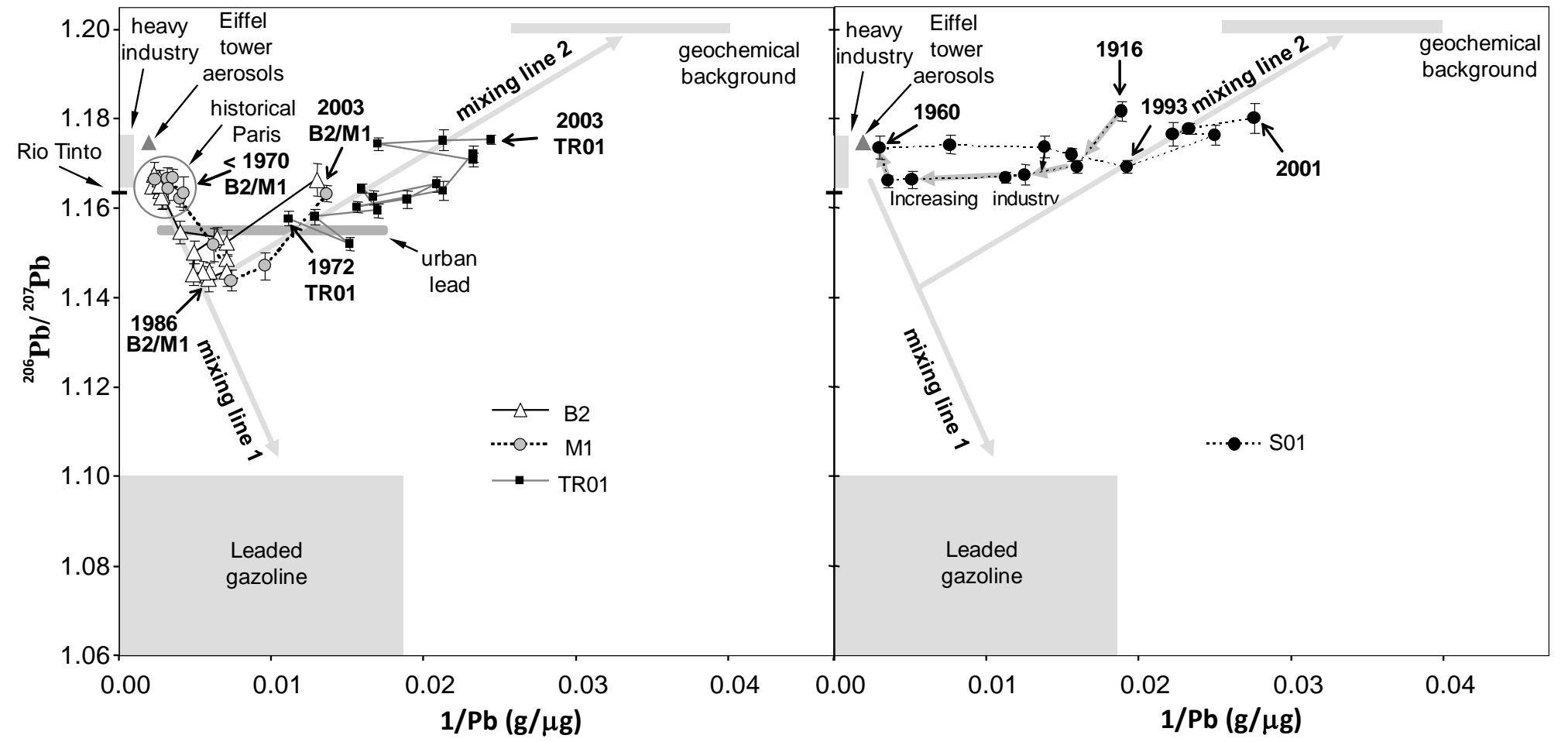


Table 1. Details on the four analysed cores sampled in the Seine River basin.

\begin{tabular}{|c|c|c|c|c|}
\hline & Upstream Seine & Oise river & \multicolumn{2}{|c|}{ Downstream Seine } \\
\hline Core reference & TR01 & S01 & B2 & M1 \\
\hline More recent strata & 2002 & 2005 & 2003 & 2003 \\
\hline More ancient strata & 1970 & 1915 & 1948 & 1934 \\
\hline $\begin{array}{l}\text { Sedimentation rate } \\
\left(\mathrm{cm} \mathrm{yr}^{-1}\right)\end{array}$ & $2.6^{\mathrm{a}}$ & $1.1^{\mathrm{b}}$ & $1.1^{\mathrm{b}}$ & $1.8^{b}$ \\
\hline $\begin{array}{l}\text { Lead concentration } \\
\text { peak }(\mathrm{s}) \text { date }(\mathrm{s})\end{array}$ & $1976 ; 1990$ & 1960 & $1963 ; 1994$ & $1938 ; 1960$ \\
\hline $\begin{array}{l}\text { Lead concentration } \\
\text { determination } \\
\text { techniques }\end{array}$ & AAS & ICP-AES & \multicolumn{2}{|c|}{ AAS \& ICP-MS } \\
\hline Population (1940) & 130,000 & 240,000 & \multicolumn{2}{|c|}{$9,000,000$} \\
\hline Population (2000) & 180,000 & 260,000 & \multicolumn{2}{|c|}{$14,000,000$} \\
\hline
\end{tabular}


Table 2. ${ }^{206} \mathrm{~Pb} /{ }^{207} \mathrm{~Pb}$ signature of samples issued from the Seine River basin.

\begin{tabular}{|c|c|c|c|}
\hline Sample & $\begin{array}{l}\text { Sampling date / } \\
\text { sample age }\end{array}$ & ${ }^{206} \mathrm{~Pb} /{ }^{207} \mathrm{~Pb}$ & Reference \\
\hline Geochemical background & $8000 \mathrm{BP}$ & $1.2007 \pm 0.0011$ & $\begin{array}{l}\text { Elbaz-Poulichet et al. } \\
\text { (1986) }\end{array}$ \\
\hline Road dust (suburbs) & 1978 & $1.101 \pm 0.001$ & id \\
\hline Indoor dust (Paris) & $1971-1981$ & $1.120 \pm 0.001$ & id \\
\hline Street dust (Paris) & 1997 & 1.151 & Nageotte and Day (1998) \\
\hline Eiffel tower paints & 1997 & 1.174 & id \\
\hline $\begin{array}{l}\text { Municipal solid waste } \\
\text { incinerators }\end{array}$ & 2001 & $1.1550 \pm 0.0005^{\mathrm{a}}$ & Widory (2004) \\
\hline $\begin{array}{l}\text { Urban heating plants } \\
\text { (Paris) }\end{array}$ & 2003 & & \\
\hline \multirow{2}{*}{\multicolumn{2}{|c|}{$\begin{array}{r}\text { burning oil } \\
\text { burning gas }\end{array}$}} & 1.11 & id \\
\hline & & $1.14-1.20$ & id \\
\hline \multirow[t]{4}{*}{ Leaded gasoline } & $1980-1987$ & $1.10 \pm 0.04$ & Véron et al. (1999) \\
\hline & 1987-1992 & $1.08 \pm 0.03$ & id \\
\hline & 1993 & $1.09 \pm 0.02$ & id \\
\hline & 1994-1995 & $1.06 \pm 0.02$ & id \\
\hline Unleaded paints $^{\mathrm{b}}$ & >> 1940 & $1.1534 \pm 0.0066$ & Laurensot (2001) \\
\hline Leaded paints ${ }^{b}$ & $<1940$ & $1.1596 \pm 0.0023$ & id \\
\hline $\begin{array}{l}\text { Tap water (presence of } \\
\text { lead pipes, }[\mathrm{Pb}]=25 \\
\mu \mathrm{g} / \mathrm{L})\end{array}$ & $1996-1998$ & $1.1561 \pm 0.0031$ & id \\
\hline $\begin{array}{l}\text { Urban waste waters } \\
\text { (combined sewer) }\end{array}$ & 2006 & $1.154 \pm 0.002$ & This work \\
\hline
\end{tabular}


Table 3. ${ }^{206} \mathrm{~Pb} /{ }^{207} \mathrm{~Pb}$ signature of lead in ores potentially imported by France from 1900 to today.

\begin{tabular}{|c|c|c|}
\hline & ${ }^{206} \mathrm{~Pb} /{ }^{207} \mathrm{~Pb}$ & Reference \\
\hline Belgium & $1.16-1.18$ & $\begin{array}{l}\text { De Vleeschouwer et al., } 2007 \\
\text { Dejonghe et al., } 1989\end{array}$ \\
\hline \multicolumn{3}{|l|}{ Germany } \\
\hline (Harz Mountains) & $1.178 \pm 0.004$ & Alfonso et al., 2001 \\
\hline (Rammelsberg) & $1.164-1.169$ & \\
\hline (Rheinisches Schiefergebirge) & $1.159-1.185$ & Krahn and Baumann, 1996 \\
\hline $\begin{array}{r}\text { (North Eifel and North } \\
\text { Sauerland) }\end{array}$ & $\sim 1.17$ & Large et al., 1983 \\
\hline \multicolumn{3}{|l|}{ ( } \\
\hline $\begin{array}{r}\text { (Mazarrón, Cartagena) } \\
\text { (Rio Tinto) }\end{array}$ & $\begin{array}{l}1.191-1.195 \\
1.1633-1.1635\end{array}$ & $\begin{array}{l}\text { Arribas and Tosdal, } 1994 \\
\text { Marcoux., } 1998\end{array}$ \\
\hline \multicolumn{3}{|c|}{ - } \\
\hline (L’Argentière) & 1.1701 & Arribas and Tosdal, 1994 \\
\hline (La Maligne) & 1.1742 & Arribas and Tosdal, 1994 \\
\hline \multicolumn{3}{|l|}{ United Kingdom } \\
\hline $\begin{array}{r}\text { (Mendips) } \\
\text { (Debyshire) }\end{array}$ & $\begin{array}{l}1.176-1.189 \\
1.171-1.188\end{array}$ & $\begin{array}{l}\text { Alfonso et al., } 2001 \\
\text { " }\end{array}$ \\
\hline Mexico & $1.200 \pm 0.006(\mathrm{n}=48)$ & Cuming et al., 1979 \\
\hline Tunisia & $1.1971 \pm 0.0045(\mathrm{n}=11)$ & Sahnoun et al., 2009 \\
\hline Morocco & $1.1638 \pm 0.0071(\mathrm{n}=30)$ & " \\
\hline $\begin{array}{l}\text { USA (Mississippi valley-type } \\
\text { deposits) }\end{array}$ & $>1.2$ & $\begin{array}{l}\text { Deloule et al., } 1986 \text {; Kesler et } \\
\text { al., } 1994\end{array}$ \\
\hline Australia (Broken Hill) & $1.0412 \pm 0.0011$ & Townsend et al. 1998 \\
\hline
\end{tabular}

